\title{
The Polish People's Republic in the context of elections to the European Parliament of the European Community (1979)
}

In the late 1970s, the EEC witnessed the first direct elections to the European Parliament of the European Community. These elections confirmed the expansion of the political integration process of the EEC and heralded the strengthening of the European Parliament's competencies among the bodies of this grouping. The Polish People's Republic party-and-state leadership watchfully followed the debate preceding the elections in the member states, and broadly commented the debate's outcomes in the press, literature, and academic analyses. Poland was concerned with the strengthening of the European Parliament, as it was a transnational institution which was not fully understood by the politicians of the Polish People's Republic. In Poland, this institution and its activity was looked upon both from the perspective of relationships between members of the organization, and of relations between communist and capitalist countries.

The first general, direct elections to the European Parliament, which took place in 1979 in nine EEC countries, aroused concern, and, as a result, a great deal of interest in Poland. In particular, they were given a lot of coverage in the Polish press ("Trybuna Ludu," "Życie Warszawy," "Polityka," "Kultura") and in academic periodicals ("Sprawy Międzynarodowe," "Przegląd Zachodni," "Kapitalizm"). The activities of the European Parliament, and specifically of the Committee on Political Affairs forming a separate part thereof, were also of interest to the Ministry of the Interior of the Polish People's Republic. ${ }^{1}$

${ }^{1}$ In July 1984, in the Ministry of the Interior of the Polish People's Republic, a confidential document was drawn up on the activities of the European Parliament's Committee on Political Affairs as a target of intelligence operations. In a confidential memo, it was suggested that, due to the growing importance of the European Parliament in EEC structures, special attention should be paid to the Committee on Political Affairs of this body, since it made decisions on important political matters covering such topics as foreign policy, including towards communist countries, and security issues. Additionally, the Committee had working ties to key EEC institutions: the Commission of the European Community, and the Council of the European Community. It was also stressed that infiltration of a target such the Committee on Political Affairs of the European Parliament of the European Community and obtaining information, including confidential information exchanged between Community institutions, would not only make it possible to anticipate the proceedings of the Common Market, but also discredit some decisions taken in the EEC and prevent the future creation of the European Union as announced by European Community member states. The document also points out that in order to achieve this goal it is necessary to win over agents from among EEC member states to work for the Polish People's Republic. The document suggested that agents should be sought among candidates for the European Parliament, before they take up their positions in the European 
The Ministry of the Interior was concerned not only about the growing political importance of the European Parliament, but also an entrenchment of the transnational factor within the European Community. According to the Ministry's analysts, special attention should be given to the Committee on Political Affairs of the European Parliament. ${ }^{2}$ The Ministry of the Interior also recommended looking closely at the EEC's committee on security, in particular the counterintelligence unit combating the activities of the intelligence services of the communist countries. According to the Ministry, it was this very unit that had recently focused on preventing the leak of secret information covering matters of free trade, political cooperation, and relationships with third countries, including the communist bloc. As the document stressed, the administration of the Common Market states did not attach much importance to security measures when dealing with secret and confidential materials, therefore the established counterintelligence unit referred to a confidentiality order on contacts between all EEC officials and representatives of communist countries, and issued some recommendations. The order came down to the following measures:

a) "every EEC staff member must obtain permission of his or her superior and head of the department (general manager) and the Directorate-General (external affairs) to talk to a representative of a communist country,

b) any meeting should result in a memo in triplicate describing the content and nature of the conversation. Individual counterparts of the memo are for the DirectorateGeneral and the Security Service of the EEC,

c) all EEC staff members must hand over to their superiors all gifts received from representatives of communist countries,

d) no EEC staff member is allowed to remove any EEC documents from the office,

e) all EEC staff members must notify their superiors if they are entering into a marriage with a citizen of a non-member state." 3

On the other hand, analyses made by Polish diplomats and publicists emphasized that attention should be focused on the irreparable costs of the progressing unification of the European Community and the related loss of sovereignty of individual member states. Transnationality was understood unambiguously. ${ }^{4}$

Parliament. See AIPN, BU 02346/4, Komisja Polityczna Parlamentu Europejskiego jako obiektu penetracji (przenikania) wywiadowczej [European Parliament Committee on Political Affairs as an object for intelligence penetration (infiltration)], pp. 1-5.

${ }^{2}$ Archives of the Institute of National Remembrance (hereinafter A IPN), Ministry of the Interior Files Set (1954-1990), reference IPN BU 02147/24, file: Niektóre problemy wewnętrznej i zagranicznej polityki EWG w aspekcie informacyjnego i operacyjnego zainteresowania wywiadu PRL (tajne) [Some problems of internal and external EEC policy in the context of the informational and operational interests of Polish People's Republic's intelligence services (confidential)], Ministry of the Interior, Annex: "Parlament Europejski i Trybunał Sprawiedliwości oraz inne organy doradcze EWG" [European Parliament and the Court of Justice and other EEC advisory bodies], 17th Information Section, Warsaw 1978.

${ }^{3}$ Ibid.

${ }^{4}$ Hubert Kozłowski, a permanent commentator of international affairs at the weekly "Rzeczywistość," in one of his articles published in 1984 quoted Simone Veil, a French candidate to the European Parliament representing the Gaullists-Giscardists (chairperson of the European Parliament in 1979-1982), from an interview with the Die Welt weekly of February 28, 1984: "I became a European. Being a European means representing to an equal extent the interests of the German 
At that time, many documents published by the Ministry of the Interior of the Polish People's Republic stressed the need for the intelligence services to infiltrate the European Parliament. ${ }^{5}$ It was treated as a significant institution whose representatives maintained contacts with other officers within the EEC structures. Many of them later became Members of the European Parliament, and some, having completed work at the EP, returned to their native countries to hold high governmental positions. Some of these people held dual national and transnational mandates. The Ministry of the Interior counted on winning over such influential agents from these countries. It was assumed that with the increasing competencies of the EP they would be able to influence the course of events within the Community. It was hoped that the recruited members of the parliamentary groups in the EP, such as those of the communist faction, in accordance with the voting procedure, would lead to the dissolution of the Commission of the European Community and thus shake the public opinion in the EEC, demonstrate the fragility of the Community institutions and would ultimately lead to a crisis in the EEC.

The documents also underlined that, not only had the EP's competencies increased, but so had its importance, which had recently been confirmed by the acceptance by the Council of Ministers of the EC of more than two-thirds of the amendments proposed by the EP. These amendments were not tabled by members of the general public, but rather by scientists, lawyers, and experts in various fields who sat in the units created by the EP (Committee on Political Affairs, Economic Committee, Monetary Committee, Energy Committee) and had access to confidential information which could not be published, ${ }^{6}$ and the expertise desired by the authorities of the Polish People's Republic. The winning over of such valuable people from the EEC by the intelligence services could have had a positive impact on the maneuvering of the government of the Polish People's Republic. Taking such reasoning into account, along with the fact that, due to the Single European Act being prepared by Genscher and Colombo, the significance of the European Parliament was set to increase even more, the document postulated increasing intelligence interest in this institution.

As the date of the elections to the European Parliament approached, more and more information appeared in the Polish press on this institution and its competencies in the structure of Community bodies.

By early 1979, Wojciech Sadurski, a columnist at the "Polityka" weekly, when announcing the upcoming elections to the European Parliament in June of that year, posed several questions that were important from the point of view of the Polish People's Republic: will the European Parliament elected by direct general elections seek to extend its powers, and will it want to make its position similar to that of national

and French nations." In the opinion of Kozłowski, Veil's statement means that the pro-western Europeanism is a resignation of own national interests to the benefit of the interests of Greater German imperialism, while the European institutions (European Parliament) are to be used for this purpose in an anti-Polish spirit.

${ }^{5}$ A IPN BU 02346/4, Teczka dokumentacji obiektowej - Parlament Europejski [Object documentation file - European Parliament], confidential document of April 11, 1983.

${ }^{6}$ Ibid. 
parliaments, i.e. become a legislative body for all nine countries? ${ }^{7} \mathrm{He}$ also pondered the impact of the elections on the general European situation and, above all, on Poland. Answering these questions, the author pointed out that Poland was already feeling the effects of the process of economic integration, as this process entailed the application of protectionist measures against Poland and other communist countries. Sadurski predicted that the progressive political integration within the European Community, reflected, inter alia, in the elections to the European Parliament, would introduce an even greater division in Europe, as the EEC would separate itself from the rest of Europe.

Evaluating the landmark first elections to the European Parliament of the EEC, Polish journalists and scholars appreciated the progress on the path of political integration of the 'nine'. In their publications, they even stressed that the elections would leave the Community stronger, more ready for change, and capable of welcoming new members to the organization. Moreover, as they argued, the Community would become an even bigger and more consolidated economic and political organism, with which the communist states, including Poland, would have to compete effectively.

At the same time, they mentioned that the process of the deepening political integration caused many disputes within the EEC, since, until that time, the member states had been driven by national interest, rather than by transnational cooperation. Polish journalists particularly strongly stressed public disapproval within the Community member states regarding the elections to the European Parliament. Polish academic and press publications suggested that Europeans did not understand the difference between national parliaments and a Community body. Interestingly, even the leading politicians of EEC member states were unable to accurately define the competencies of the European Parliament elected in 1979, which was also pointed out in Polish publications.

Even before the June elections to the European Parliament, the Polish press reported on the pessimistic mood among Danes and the growing number of opponents of their country's presence in the European Community. As Rudolf Hoffman wrote in "Życie Warszawy" in the article Danish Fears and Protests: "after Denmark's 7-year long history in the Common Market, only 55\% of Danes are in favor of remaining in the EEC, while $45 \%$ are against it." "The author argued that the Danes' somber mood was the result of rising inflation, unemployment, uncompetitive industry of Demark in comparison with the Federal Republic of Germany, France, and the Netherlands, and a deficit in the balance of payments to foreign countries. Further in the article, the journalist stressed that it was not surprising that, in the present situation, as many as five of the fifteen deputies running for the EEC parliament might be opposed to membership of this institution. It was them who reportedly claimed on the forum of the European Parliament that there was a growing opposition to the European Community in Denmark. He also pointed out that some EEC countries, such as Germany, had already undertaken the mission of convincing Danes that they had chosen the right path when

7 W. Sadurski, Nowy, stary parlament [New, old parliament], "Polityka," January 20, 1979, p. 11.

8 R. Hoffman, Przed wyborami do Parlamentu EWG. Duńskie obawy i protesty [Before the EEC parliamentary elections. Danish concerns and protests], “Życie Warszawy” of 6 June 1979, p. 4. 
they joined the EEC in October 1972. ${ }^{9}$ In April 1972, Willy Brandt, the Chairman of the SPD, supported the Danes in their Scandinavian mission in the EEC and stressed the necessity of Denmark's accession to the European Community.

On the other hand, Leszek Kołodziejczyk, in an article in "Polityka" entitled The French and the Community, analyzing the pre-election mood in France, stressed that the average French citizen was confused about the upcoming elections to the European Parliament; moreover, they were of less interest to him than the elections to any national bodies. ${ }^{10}$ Later in the long article, the journalist stressed that pre-election polls indicated that, in Strasbourg, the majority of the 81 deputies would be supporters of the European integration processes (with Simone Veil heading the pro-presidential UDF, alongside the socialists, headed by François Mitterrand).

On the other hand, in "Trybuna Ludu," Zbigniew Leśnikowski drew attention to a significant problem related to the elections, namely the inclusion of West Berlin. ${ }^{11}$ It should be mentioned here that, in accordance with the law on the election of German MPs to the European Parliament, it was envisaged that three parliamentarians from West Berlin would participate in the work of the future European Parliament as members of the Federal Republic of Germany. The journalist criticized this situation. Referring to an article published in the Soviet "Pravda," he emphasized that these actions were contrary to the agreement on the special status of West Berlin. According to Leśnikowski, the inclusion of West Berlin in the elections would lead to the extension of EEC competency over West Berlin and, in addition, to the violation of the Helsinki Agreements. In the 1970s, when the significance of the Federal Republic of Germany in the integration structures of the EEC significantly increased, the party-and-state leaders in Poland suggested that the EEC member states, and Germany in particular, driven by different motives, insisted on the possibility of peaceful modifications of the borders, ${ }^{12}$ which defied the foreign policy priorities of the Polish People's Republic.

Zenon Nowak, Ambassador of the Polish People's Republic to the USSR, also expressed his fear regarding the inclusion of West Berlin in the European Parliament. In a confidential cryptogram sent to the then Deputy Minister of Foreign Affairs of the Polish People's Republic, Józef Czyrek, the diplomat pointed out that the accession of West Berlin to the European Parliament basically had one goal: to merge West Berlin with the Federal Republic of Germany, which would de facto lead to the latter representing the former. ${ }^{13}$

${ }^{9}$ In October 1972 a referendum was held in Denmark, as a result of which $63 \%$ of the population voted in favor of the accession to the EEC and 37\% against.

${ }^{10}$ L. Kołodziejczyk, Francuzi i Wspólnota [The French and the Community], "Polityka," June 9, 1979, p. 11.

${ }^{11}$ Z. Leśnikowski, Berlin Zachodni w wyborach zachodnioeuropejskiego zgromadzenia [West Berlin and the European Elections], "Trybuna Ludu" of June 8, 1979, p. 2.

${ }_{12}$ AAN, 1354 Central Committee of the Polish United Workers' Party, ref. XI/147, Office of the Secretariat, Information of the Politburo about the international situation and foreign policy at the 17th Plenary Session of the Central Committee of the Polish United Workers' Party of May 12, 1975.

${ }^{13}$ Nowak to Czyrek, Moscow-based ambassador's confidential cryptogram: "Soviet comments on West Berlin," November 18, 1976, in: Polskie Dokumenty Dyplomatyczne, ed. P. Długołęcki, PISM, Warszawa 2008, p. 820. 
On the day of the initiation of the three-day elections to the European Parliament, Zdzisław Kamiński, another well-known publicist from "Życie Warszawy," listed the rights of the newly elected Members of the European Parliament, to demonstrate how minimal these rights were. ${ }^{14}$ In the assessment of the competencies of the European Parliament, he pointed out that this body had little power to exercise parliamentary control over the EEC governing body: "MPs discuss only the annual reports submitted to them by this body, and pass certain recommendations concerning that document; the Parliament has the right to table amendments to the EEC budget, and has advisory powers when requested to do so by other EEC institutions. ${ }^{" 15}$ Later in the article, Kamiński argued that the political integration of the EEC, of which the aforementioned elections were a part, was an attempt by the elites of the EEC to make up for the losses resulting from economic integration. As he noted, it was also part of the political process in the EEC and part of the most important aim that the Common Market was now striving for, i.e. a political union presented in the report of Leo Tindemans (1975) - an enthusiast of the Common Market and the leader of the Christian Democrat grouping in the European Parliament. Kamiński believed that the EP elections, in the vast majority of EEC countries, did not arouse much interest; and in Italy, for example, where voting was compulsory, the parliamentary elections just before the European elections were in fact a 'warm-up' before the European Parliament elections. In the final part of the article, Kamiński emphasized the reluctance of communist parties towards this institution, which supposedly reinforced the division on the Old Continent and significantly hindered cooperation between countries with different political leanings.

On June 7-10, 1979, elections to the European Parliament were held in the countries of the (then) 'nine'. At that time, the Polish press systematically reported on the results of the elections and their impact on the internal situation of the EEC countries. A long-term assessment of the impact of the election results on the whole Community was also made. Over time, attempts were made to answer the question of their impact on relations between the communist and capitalist states (EEC), as well as between Poland and the EEC.

On June 8, Zbigniew Ramotowski expressed in "Trybuna Ludu" a very negative opinion of the European election campaign in the Federal Republic of Germany and argued that West German society did not see any point in electoral participation: "despite hundreds of thousands of posters and leaflets, pamphlets, advertisements in the press, special programs on the radio and television, as well as a large number of meetings and rallies, the citizens of the Federal Republic of Germany often do not know who they are electing, why, and for what purpose, on June 10."16

On the other hand, Tadeusz Jacewicz wrote in the same newspaper that apathy won the elections to the Western European Parliament. ${ }^{17}$ In his opinion, such a low turnout

${ }^{14}$ Z. Kamiński, Elekcja bez entuzjazmu [Elections without Enthusiasm], “Życie Warszawy” of June 7, 1979, p. 9.

15 Ibid.

${ }_{16}$ Z. Ramotowski, Wybory do parlamentu EWG. Złożony proces [Elections to the Parliament of the EEC. A complex process], "Życie Warszawy" of June 8, 1979, p. 4.

17 T. Jacewicz, Wybory do Parlamentu Europejskiego EWG. Demonstracja rozczarowania [Elections to the European Parliament of the EEC. A demonstration of disappointment], "Trybuna Ludu" of June 9-10, 1979, p. 2. 
was the result of British society's disappointment with the situation on the Common Market. The London correspondent of this daily claimed that the decision for the UK to join the EEC went against the will of the British people.

"Życie Warszawy" also reported the apathy of voters in Europe and their lack of interest in the elections to the EC Parliament. Leszek Kołodziejczyk evaluated the results of the elections in the United Kingdom, the Netherlands, Denmark, and Ireland. As he noted, in the first three countries, every second eligible voter did not vote, and only in Ireland was there significant interest: "Denmark broke the record of indifference, where more than half of those entitled did not participate." 18 Later in the article, the journalist stated that elections to the European Parliament were part of the process of political unification of the Old Continent, and that they were supported by the committees of the political parties in EEC countries, but not by the public. In his opinion, the problem was also that politicians could not explain the changes in EEC institutions after the elections to the aforementioned parliament.

"Trybuna Ludu" also evaluated the elections to the Western European Parliament from the point of view of the victory of individual political groupings and the impact of this on the situation in the 'nine.' While the most commonly-reported information was on low election turnout (turnout averaged 53.25\%), the press also reported the victory of the Giscardists in France (25 seats in the EEC parliament), the Christian Democracy Party in Italy (30 seats), and the Conservative Party in the UK. ${ }^{19}$ On the other hand, the results in the Federal Republic of Germany, where the CDU/CSU coalition won a clear victory, were observed with surprise.

In "Kultura" Tadeusz Jacewicz wrote that "in the Benelux region, the prevailing belief was that the elections would not change anything [....] France saw a clash of different concepts of a political vision of a united Europe [...] In Germany, when the election results were announced, politicians had scowling faces, as more than 10 million Germans did not go to the polls. [....] On the British Isles (except Ireland) such a result was expected, since the British were split into those who did not know about the elections, those who did not care about the elections, and those who did not want the elections." 20

Kazimierz Nowak, on the other hand, disagreed with the statement of the Belgian politician, Leo Tindemans, who announced at a sitting of the European Parliament on July 17 that "the will of the European people is expressed in this Parliament, and the deputies represent the will of the nation." ${ }^{21}$ In the opinion of this economist, the European Parliament elected in 1979 did not have any real power, as this still belonged to the European Council.

Henryk Zdanowski, on the other hand, in a "Polityka" article, believed that the supporters of European integration, who claimed that the aforementioned elections

18 L. Kołodziejczyk, Przy braku zainteresowań społeczeństw. Wybory do parlamentu EWG [The Lack of Interest of Society in the Elections to the Parliament of the EEC], "Życie Warszawy” of June 9-10, 1979, p. 6.

19 PAP, Wyniki wyborów do parlamentu zachodnioeuropejskiego [Results of the Elections to the Western European Parliament], "Trybuna Ludu” of June 13, 1979, p. 2.

20 T. Jacewicz, Euroabsencja [Euro-abstention], "Kultura," no. 25 of June 24, 1979, p. 15.

${ }^{21}$ K. Nowak, Polityczne aspekty Parlamentu Europejskiego [Political aspects of the European Parliament], "Sprawy Międzynarodowe," No. 11 of 1980, p. 43. 
were an extremely important step in building the edifice of Western European integration, were disappointed. Low voter turnout, poor campaigning and insufficient commitments by politicians to mobilize the electorate had resulted in the "unfortunate birth of a new European Assembly." ${ }^{22}$ This columnist also stated that the political landscape had changed after the elections, as three new European parties were formed: the European People's Party, the Union of Socialist Parties, and the Federation of Liberal and Democratic Parties. However, the author of the article thought that the groupings which had emerged from national parties would not have any autonomy.

It was not only the press that commented on the results of the first elections to the European Parliament. They were also evaluated by Polish diplomats.

On June 21, 1979, Janusz Wiejacz, Director of the Department of Studies and Programming at the Ministry of Foreign Affairs, sent a circular to twenty Polish diplomatic missions, including in EEC member states. The circular focused on and evaluated the elections to the European Parliament held in the countries of the Common Market. His view of this event was very blunt. "We are critical of the Western European Community's usurping of the right to speak on behalf of the whole of Europe. In the current state of affairs, transnational integration trends and steps serve to deepen the division of Europe, and are to the benefit of the interests of the strongest member of the EEC - the Federal Republic of Germany. Low voter turnout may indicate that Western European societies do not support this integration [...] What should be carefully observed are attempts to increase the competencies of the parliament and the political ascension of center-right parties, to the detriment of the process of detente. Our opinion of the entry of MPs from West Berlin into the parliament is negative, as this is contrary to the Four-Power Agreement on Berlin., ${ }^{23}$

The elites of the Polish People's Republic expressed great interest in the first direct elections to the European Parliament. The results were analyzed from the point of view of cooperation between the countries of Western Europe. In this context, on the one hand, it was suggested that progress in the harmonization of the political activities of EEC members would, in the future, bring tangible benefits to the organization. On the other hand, it was pointed out that this progress was coupled with many disputes within the bloc. At the same time, what was stressed was the disinterest of EEC societies in participation in the decision-making processes of the bloc.

The influence of election results within the European Community on the relations between the EEC states and communist countries was also discussed. It was suggested that once the political objectives for the unification of the 'nine' were set out, when the elections were over, the 'nine' could emerge stronger, more competitive on the international arena, and ready for further challenges, such as the accession of new members to the bloc. In this context, the question of the development of trade relations between the COMECON and the EEC remained open.

${ }^{22}$ H. Zdanowski, Źle urodzone [Off to a bad start], "Polityka" of June 23, 1979, p. 12.

${ }^{23}$ Polish Diplomatic Documents, Circular of the Director of the Department of Studies and Programing of J. Wiejacz to the heads of permanent missions of the Polish People's Republic about the elections to the European Parliament, (confidential), June 21, 1979, p. 178. 


\section{Bibliography}

\section{Sources:}

AIPN, BU 02346/4, Komisja Polityczna Parlamentu Europejskiego jako obiektu penetracji (przenikania) wywiadowczej [European Parliament Committee on Political Affairs as an object for intelligence penetration (infiltration)].

Archives of the Institute of National Remembrance (hereinafter A IPN), Ministry of the Interior Files Set (1954-1990), reference IPN BU 02147/24, file: Niektóre problemy wewnętrznej i zagranicznej polityki EWG $w$ aspekcie informacyjnego $i$ operacyjnego zainteresowania wywiadu PRL (tajne) [Some problems of internal and external EEC policy in the context of information and operational interest of Polish People's Republic's intelligence (confidential) [, Ministry of the Interior, Annex: "Parlament Europejski i Trybunał Sprawiedliwości oraz inne organy doradcze EWG" [European Parliament and the Court of Justice and other EEC advisory bodies], 17th Information Section, Warsaw 1978.

A IPN BU 02346/4, Teczka dokumentacji obiektowej-Parlament Europejski [Object documentation file - European Parliament], confidential document of April 11, 1983.

AAN, 1354 Central Committee of the Polish United Workers' Party, ref. XI/147, Office of the Secretariat, Informacja Biura Politycznego o sytuacji międzynarodowej i polityce zagranicznej [Information of the Politburo about the international situation and foreign policy] at the 17th Plenary Session of the Central Committee of the Polish United Workers' Party of May 12, 1975.

\section{Published documents:}

Confidential cryptogram of the ambassador in Moscow: Soviet comments on West Berlin, November 18, 1976 (2008), in: Polskie Dokumenty Dyplomatyczne 1976, ed. P. Długołęcki, PISM, Warszawa.

\section{Studies:}

Hoffman R. (1979), Przed wyborami do Parlamentu EWG. Duńskie obawy i protesty, "Życie Warszawy" of June 6.

Jacewicz T. (1979), Wybory do Parlamentu Europejskiego EWG. Demonstracja rozczarowania, "Trybuna Ludu" of June 9-10.

Jacewicz T. (1979), Euroabsencja, “Kultura," no. 25 of June 24.

Kamiński Z. (1979), Elekcja bez entuzjazmu, “Życie Warszawy” of June 7.

Kołodziejczyk L. (1979), Francuzi i Wspólnota, "Polityka” of June 9.

Kołodziejczyk L. (1979), Przy braku zainteresowań społeczeństw. Wybory do parlamentu EWG, “Życie Warszawy" of June 9-10.

Leśnikowski Z. (1979), Berlin Zachodni w wyborach zachodnioeuropejskiego zgromadzenia, "Trybuna Ludu" of June 8.

Nowak K. (1979), Polityczne aspekty Parlamentu Europejskiego, “Sprawy Międzynarodowe,” no. 11. Ramotowski Z. (1979), Wybory do Parlamentu EWG. Złożony proces, “Życie Warszawy” of June 8. Sadurski W. (1979), Nowy, stary parlament, "Polityka” of January 20.

\section{Summary}

The paper shows insight into the Polish response to the elections to the European Parliament held in 1979. It focuses on the opinions presented by journalists in the Polish press, and also highlights the response of the Ministry of the Interior of the Polish People's Republic to the 
EEC's political unification process announced after 1975. The paper also presents the response of the public in the EEC 'nine' to the important event that the elections to the European Parliament were.

Key words: European Parliament, elections, European Community, Polish People's Republic

PRL wobec wyborów do Parlamentu Europejskiego Wspólnot Europejskich z 1979 roku

\section{Streszczenie}

W artykule przybliżono polskie reakcje na organizację wyborów do Parlamentu Europejskiego w 1979 roku. Skoncentrowano się na opiniach publicystów prasy polskiej, zwrócono także uwagę na reakcje Ministerstwa Spraw Wewnętrznych PRL na zapowiadany po 1975 roku proces unifikacji politycznej EWG. Przedstawiono również reakcje społeczeństw państw „dziewiątki" na niebagatelne wydarzenie, jakim były wybory do Parlamentu Europejskiego.

Słowa kluczowe: Parlament Europejski, wybory, Wspólnoty Europejskie, PRL 